\section{Internally Controlled Poly(A) Tail Assay to Study Gene Regulation}

BioTechniques 33:476-480 (September 2002)

Completion of genomic sequencing in several organisms, including humans, flies, and worms, and the resulting realization of the relatively small number of genes has led to a focus on understanding the functional diversity of encoded mRNAs and proteins. Many post-genomic era efforts require a detailed understanding of gene expression regulation, which is crucial to cell metabolism, development, and differentiation.

mRNA poly(A) tail length is indicative of both translatability and stability. Its regulation via cytoplasmic polyadenylation affects diverse processes including synaptic plasticity (9) and embryonic development $(5,8)$. One notable example, maternal mRNAs in development, are synthesized in the mother, stored in the egg in translationally silent form, and quickly deployed translationally after fertilization. Cytoplasmic polyadenylation parallels their translational activation, and subsequent deadenylation often participates in their ultimate degradation (8).

During our studies of Drosophila temporal gene regulation, we were interested in maternal mRNA metabolism throughout a developmental period. We sampled populations of developing embryos at different times, extracted their RNA, and analyzed the polyadenylation patterns of different maternal transcripts as an indicator of their translatability. We employed the poly(A) tail (PAT) assay, a sensitive PCR-based technique that analyzes the poly(A) tail length of a given mRNA species within a population $(6,7)$. While gene expression studies have employed this technique, we realized that informative sample comparison could be compromised by both physiological and experimental variation. Biologically, maternal mRNA (e.g., bicoid) amounts decrease over time, reflecting physiological changes during development. Logistically, the PAT assay generates PCR templates by multiple sensitive steps: poly(dT) primers equal in length to each messages'
poly(A) tail are produced by oligo d(T) annealing-ligation, an anchor oligonucleotide is then ligated to the $3^{\prime}$-end, and cDNAs are generated by reverse transcription $(6,7)$. In this as in every RTPCR-based technique, cDNA synthesis efficiency is crucial to the faithful representation of template RNAs. To overcome inherent problems created by both these issues, we devised a means to internally control our PAT assays. Here we describe the resulting modified, internally controlled PAT assay with which we could reliably compare different samples within the same time course (e.g., throughout development) and different sample sets (e.g., from different genotypes).

We designed a synthetic polyadenylated mRNA of definite size to mix in a set amount with each experimental RNA sample (Figure 1A). This RNA would undergo every PAT assay step and would be amplified competitively with the endogenous (test) mRNA. Since we study bicoid ( $b c d$ ) mRNA, a

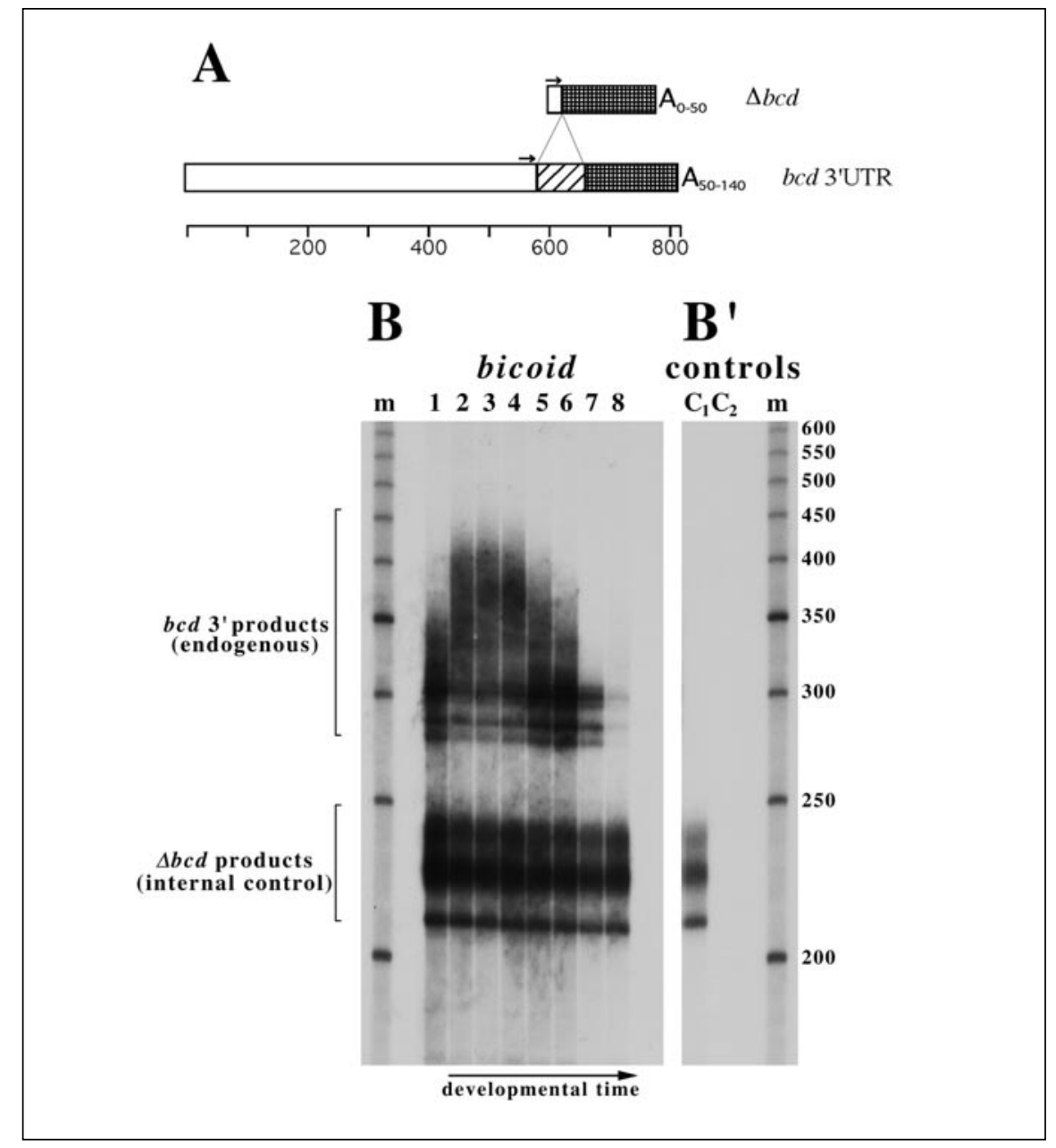

Figure 1. Internally controlled PAT assay. (A) $\Delta b c d$ internal control design. $b c d 3^{\prime}$-UTR (bottom) and $\Delta b c d$ RNA (top) are shown to scale. Patterns denote areas of identical sequence. The $b c d$-specific primer site (arrows, not to scale) and the anchor ligated at the RNA poly(A) tail were used for amplification. Internal deletion of the $b c d 3^{\prime}$-UTR was generated by PCR mutagenesis (2). (B and $\mathrm{B}^{\prime}$ ) Time course of $b c d$ mRNA poly(A) tail dynamics during development via the internally controlled PAT assay. Samples from Drosophila ovaries (lane 1) and embryos of increasing age (lanes 2-8) were amplified and gel-fractionated. Embryo ages following development at $20^{\circ} \mathrm{C}$ were $0-1 \mathrm{~h} 30 \mathrm{~min}$ (lane 2), $20 \mathrm{~min}$ to $1 \mathrm{~h} 50 \mathrm{~min}$ (lane 3), $1 \mathrm{~h} 10 \mathrm{~min}$ to $2 \mathrm{~h} 40 \mathrm{~min}$ (lane 4), $2 \mathrm{~h} 5 \mathrm{~min}$ to $3 \mathrm{~h} 35 \mathrm{~min}$ (lane 5), $2 \mathrm{~h} 54 \mathrm{~min}$ to $3 \mathrm{~h} 24 \mathrm{~min}$ (lane 6), $3 \mathrm{~h} 45 \mathrm{~min}$ to $5 \mathrm{~h} 15 \mathrm{~min}$ (lane 7), and $4 \mathrm{~h} 46 \mathrm{~min}$ to $6 \mathrm{~h} 16 \mathrm{~min}$ (lane 8). Endogenous and synthetic internal control RNA products are indicated. Heterogeneity reflects the poly(A) tail size range in the corresponding $b c d$ populations. ( $\left.\mathrm{B}^{\prime}\right)$ PAT controls processed in parallel and separated electrophoretically on the same gel as in panel B. $\mathrm{C}_{1}$, cDNA synthesis control (only $\Delta b c d$ RNA); $\mathrm{C}_{2}$, PCR control (no cDNA template); $\mathrm{m}$, size markers. 
Table 1. Protocol for Internally Controlled and Optimized PAT Assay

1. Design an internal control related to your test RNA as indicated in the text.

2. Add a set amount of polyadenylated internal control RNA to $0.5 \mu \mathrm{g}$ each experimental sample at a concentration allowing competitive amplification. Add 5 '-phosphorylated oligo $\mathrm{d}(\mathrm{T})(0.3 \mu \mathrm{g}$; Invitrogen) and bring to a final volume of $8 \mu \mathrm{L}$ with RNase-free water.

3. Heat-denature RNA at $65^{\circ} \mathrm{C}$ for $5 \mathrm{~min}$.

4. Pre-warm sample at $42^{\circ} \mathrm{C}$ for $2 \mathrm{~min}$.

5. Add $13 \mu \mathrm{L}$ mixture $\mathrm{A}: 1.5 \times$ first-strand buffer $(75 \mathrm{mM}$ Tris- $\mathrm{HCl}, \mathrm{pH} 8.3,112.5$ $\mathrm{mM} \mathrm{KCl}, 4.5 \mathrm{mM} \mathrm{MgCl}_{2}$ ), $3.8 \mathrm{mM}$ DTT, $1.7 \mathrm{mM}$ ATP, 5 U RNasin ${ }^{\circledR}$ (Promega, Madison, WI, USA), $40 \mu \mathrm{M}$ dNTPs, $18000 \mathrm{U}$ T4 DNA ligase (New England Biolabs, Beverly, MA, USA), and incubate at $42^{\circ} \mathrm{C}$ for $30 \mathrm{~min}$. Here mRNA and control poly $(A)$ tails are saturated with annealed oligo $d(T)$ primers, which are then ligated together.

6. Add the anchor oligonucleotide (50 pmol in $0.5 \mu \mathrm{L}, 5^{\prime}$-GCGAGCTCCGCGGC$\mathrm{CGCGT}_{\left.12^{-} 3^{\prime}\right)}(6)$ and incubate at $12^{\circ} \mathrm{C}$ for $2 \mathrm{~h}$. This step completes the $\mathrm{d}(\mathrm{T})$ saturation of mRNA $3^{\prime}$-ends and adds a GC-rich end (anchor) to facilitate subsequent PCR amplification.

7. Pre-warm reaction mixtures for 2 min at $42^{\circ} \mathrm{C}$, add $200 \mathrm{U}$ SUPERSCRIPT IITM reverse transcriptase (Invitrogen), and incubate at $42^{\circ} \mathrm{C}$ for $1 \mathrm{~h}$. cDNAs are synthesized, extending the compound oligo $d(T)$-anchor oligonucleotide annealed to the mRNA 3'-ends.

8. Heat-inactivate the $\mathrm{RT}$ reaction at $70^{\circ} \mathrm{C}$ for $30 \mathrm{~min}$.

9. PCR-amplify $0.5-1 \mu \mathrm{L}$ each RT reaction in a heated-lid thermal cycler (model PE9700) with the steepest thermal ramp possible. A typical reaction contains $1 \times$ PCR buffer (proprietary formula; Qiagen, Valencia, CA, USA), $200 \mu \mathrm{M}$ dNTPs, 25 pmol each of the anchor- and gene-specific primers ( $b c d$-specific primer: 5'-CATTTGCGCATTCTTTGACCAAGAA-3', anchor: 5'-GCGAGCTCCGCGGCCGCGT $\left._{12}-3^{\prime}\right)(6), 0.25 \mu \mathrm{L} \alpha\left[{ }^{32} \mathrm{P}\right] \mathrm{dATP}(3000 \mathrm{Ci} / \mathrm{mmol})$ and $0.5 \mathrm{U}$ Taq DNA polymerase (Qiagen) in a total volume of $50 \mu \mathrm{L}$. Sample amplification parameters for $b c d$ and other Drosophila maternal mRNAs: denaturation at $94^{\circ} \mathrm{C}$ for $5 \mathrm{~min}$, followed by 28 cycles of $94^{\circ} \mathrm{C}$ for $30 \mathrm{~s}, 62^{\circ} \mathrm{C}$ for $30 \mathrm{~s}$, and $72^{\circ} \mathrm{C}$ for $30 \mathrm{~s}$, and by a final extension-repair at $72^{\circ} \mathrm{C}$ for $7 \mathrm{~min}$.

10. Remove unincorporated nucleotides by Sephadex-G50 filtration and dry equal volumes of each reaction $(25-40 \mu \mathrm{L})$ in a SpeedVac ${ }^{\circledR}$ concentrator (Thermo Savant, Holbrook, NY, USA).

11. Resuspend samples in $10 \mu \mathrm{L} 95 \%$ formamide, $0.05 \%$ SDS, $0.05 \%$ bromophenol blue, $0.05 \%$ xylene cyanol FF.

12. Denature at $95^{\circ} \mathrm{C}$ for $5 \mathrm{~min}$ and resolve on a $0.5 \times$ TBE $8 \%$ polyacrylamide 7 $\mathrm{M}$ urea gel. Dry gel and visualize by autoradiography.

seminal factor in Drosophila development (1), we designed a $b c d$-related internal control $(\Delta b c d)$. The plasmid encoding $\Delta b c d \quad(\mathrm{pBS} \Delta b c d 1)$ was pBlueScript ${ }^{\circledR}$ SKII containing $(i)$ a T7 promoter, (ii) a bcd $3^{\prime}$ untranslated region (UTR) subset (nucleotide 2201 to the 3 '-end), (iii) an internal 81-bp deletion (bcd nucleotides 2225-2306) to generate a control with electrophoretic mobility distinct from endogenous $b c d$ products, and (iv) a $b c d$-specific primer annealing site for PAT analysis to allow competitive amplification of endogenous and control bcd species (Figure 1A). These features can be applied to any mRNA of choice.

pBS $\Delta b c d 1$, linearized after the insert, was transcribed in vitro by $\mathrm{T} 7$ RNA polymerase with $\gamma\left[{ }^{32} \mathrm{P}\right] \mathrm{GTP}(4)$, yielding 5 '-end-labeled molecules. Transcripts $(10 \mathrm{nmol})$ were then poly- adenylated in vitro with poly(A) polymerase (PAP, 2 U/nmol RNA) in the presence of manganese $(20 \mathrm{mM}$ Tris$\mathrm{HCl}, \mathrm{pH}$ 7.0, 0.125 mM EDTA, $60 \mathrm{mM}$ $\mathrm{KCl}, 0.7 \mathrm{mM} \mathrm{MnCl}_{2}, 0.7 \mathrm{mM}$ ATP, 40 $\mu \mathrm{g} / \mathrm{mL}$ tRNA, $5 \mathrm{mM}$ DTT, $10 \%$ glycerol, $0.1 \mathrm{mg} / \mathrm{mL} \mathrm{BSA}$ ) at $37^{\circ} \mathrm{C}$ (3). Under these conditions, PAP polyadenylates RNA 3 '-ends independent of sequence. Every PAP batch (made inhouse or commercially) required titration before use. The optimal incubation time (here $5 \mathrm{~min}$ ) yielded a peak of molecules with poly(A) tails in the desired size range. For $\Delta b c d$, we chose a poly(A) tail of 0-50 nucleotides; this range controls well for endogenous $b c d$ poly(A) variations [elongation from 50 to approximately 140 As upon translational activation, followed by complete deadenylation and degradation $(6,7)]$. This is in the lowest range for PAP, which can efficiently add several hundred As in vitro (3). Polyadenylated molecules were size-selected by electrophoresis on polyacrylamide-urea gels, and the $5^{\prime}$ label was eventually removed by phosphatase and Sephadex ${ }^{\circledR}$ G50 filtration. The resulting polyadenylated $\Delta b c d$ RNA was aliquoted and stored in ethanol at $-80^{\circ} \mathrm{C}$.

To analyze endogenous $b c d$ poly(A) tail dynamics, identical $\Delta b c d$ amounts were added to each test sample, and pools were simultaneously subjected to PAT analyses. The basic protocol of Sallés et al. $(6,7)$ was used, along with the modifications described below.

Competitive amplification of endogenous sample RNA and the synthetic internal control requires an optimal ratio between these two RNA species. This was determined empirically by titrating poly(A)-tailed $\Delta b c d$ amounts from three gel-purified fractions (typically fmol). Titration of total RNA amounts and PCR cycles may be critical to obtain informative PAT assay results, particularly when dealing with mRNAs whose levels vary over the time analyzed. Together, the incorporation of the internal control and the delineated modifications contribute to assay efficiency, reproducibility, and reliability, which are essential in comparative analyses.

In addition to obviously using identical template RNA amounts in each reaction (in our hands, $0.5 \mu \mathrm{g}$ total Dro- 
sophila embryonic RNA 0-7 h of development), two other parameters were important to obtain reproducible results. First, RNA quality was vital to maximize poly(A) tail saturation by oligo $\mathrm{d}(\mathrm{T})$ and to minimize amplification background. Among the RNA extraction methods tested, we obtained optimal results (data not shown) using RNA extracted with TRIzoL ${ }^{\circledR}$ (Invitrogen, Carlsbad, CA, USA), which was then subject to further deproteinization in a buffer containing $50 \mathrm{mM}$ Tris- $\mathrm{HCl}$, pH 8.0, 2 mM EDTA, 0.5\% SDS, 0.3 M sodium acetate, $0.1 \mathrm{mg} / \mathrm{mL}$ proteinase $\mathrm{K}$ for $30 \mathrm{~min}$ at $65^{\circ} \mathrm{C}$, two phenol:chloroform and one chloroform extractions, and ethanol precipitation. While this was the case for Drosophila embryonic material, it may be generally applicable to RNA derived from many developing organisms since considerable changes occur upon membrane synthesis and cellularization. These changes can conceivably affect RNA extraction efficiency and/or leave residues that inhibit the PAT assay's delicate steps. Consistently, when the second deproteinization step was omitted, our $\Delta b c d$ control was processed with unequal efficiency in parallel samples (data not shown); this indicated inefficient processing of endogenous mRNA and therefore precluded proper result interpretation. Second, the use of a heated-lid thermal cycler (model PE9700; Perkin Elmer Life Sciences, Gaithersburg, MD, USA) increased the signal-to-noise ratio. It also decreased the amount of [ $\left.{ }^{32} \mathrm{P}\right]$-labeled nucleotide needed to monitor the reaction (Table 1).

Figure 1B shows an example of sample RNA from Drosophila wildtype ovaries (lane 1) and embryos (lanes 2-8) processed by this modified method. In the ovary, $b c d$ is translationally inactive and exhibits short poly(A) tails (approximately 50 nucleotides, agreeing with Reference 7). Upon fertilization, $b c d$ poly(A) tails are quickly elongated (lanes 2-4), subsequently deadenylated (lanes 5-7), and this mRNA is eventually degraded (lane 8 ). The $\Delta b c d$ internal control product is comparable in all lanes, showing that the experimental steps proceeded with similar efficiency in all samples and equal sample was loaded in every lane. Therefore, samples can be directly compared and reliable information can now be obtained. We believe this internally controlled PAT assay represents a valuable tool for comparative, multisample studies and can be applied when analyzing functional responses to developmental, chemical, environmental, and differentiation stimuli.

\section{REFERENCES}

1.Berleth, T., M. Burri, G. Thoma, D. Bopp, S. Richstein, G. Frigerio, M. Noll, and C. Nüsslein-Volhard. 1988. The role of localization of bicoid mRNA in organizing the anterior pattern of the Drosophila embryo. EMBO J. 7:1749-1756.

2.Gamberi, C., D. Peterson, L. He, and E. Gottlieb. 2002. An anterior function for the Drosophila posterior determinant Pumilio. Development. 129:2699-2710.

3.Gunderson, S.I., S. Vagner, M. PolycarpouSchwarz, and I.W. Mattaj. 1997. Involvement of the carboxyl terminus of vertebrate poly(A) polymerase in U1A autoregulation and the coupling of splicing and polyadenylation. Genes Dev. 11:761-773.

4.Milligan, J.F., and O.C. Uhlenbeck. 1989. Synthesis of small RNAs using T7 RNA polymerase. Methods Enzymol. 180:51-62.

5.Richter, J. 2000. Influence of polyadenylation-induced translation on metazoan development and neuronal synaptic function, p. 785805. In N. Sonenberg, J.W.B. Hershey, and M.B. Mathews (Eds.), Translational Control of Gene Expression. CSH Laboratory Press, Cold Spring Harbor, NY.

6.Sallés, F.J., M.E. Lieberfarb, C. Wreden, J.P. Gergen, and S. Strickland. 1994. Coordinate initiation of Drosophila development by regulated polyadenylation of maternal messenger RNAs. Science 266:1996-1999.

7.Sallés, F.J. and S. Strickland. 1995. Rapid and sensitive analysis of mRNA polyadenylation states by PCR. PCR. Methods Appl. 4:317-321.

8.Wickens, M., E. Goodwin, J. Kimble, S. Strickland, and M.W. Hentze. 2000. Translational control of developmental decisions, $\mathrm{p}$. 295-370. In N. Sonenberg, J.W.B. Hershey, and M.B. Mathews (Eds.), Translational Control of Gene Expression. CSH Laboratory Press, Cold Spring Harbor, NY.

9.Wu, L., D. Wells, J. Tay, D. Mendis, M.A. Abbott, A. Barnitt, E. Quinlan, A. Heynen, J.R. Fallon, and J.D. Richter. 1998. CPEBmediated cytoplasmic polyadenylation and the regulation of experience-dependent translation of $\alpha$-CaMKII mRNA at synapses. Neuron 21:1129-1139.

We thank Fernando Sallés and Sam Gunderson for early discussions and S.G. for the PAP plasmid. This work was funded by National Institutes of Health grant no. RO1 GM50800 to E.G. Address correspondence to Dr. Ellen Gottlieb, Institute for
Cellular and Molecular Biology, Section of Molecular Genetics and Microbiology, University of Texas at Austin, 2500 Speedway, Austin, TX 78712,USA.e-mail: egottlieb@ mail.utexas.edu

Received 2 April 2002; accepted 3 May 2002.

\section{Chiara Gamberi and Ellen Gottlieb}

University of Texas at Austin

Austin, TX, USA

For reprints of this or any other article, contact Reprints@BioTechniques.com

\section{Simple Device to Deliver Beads to 96-Well Plates for Rapid Resuspension of Bacterial Pellets}

\section{BioTechniques 33:480-482 (September 2002)}

Genomic sequence determination relies heavily on sequencing large numbers of plasmids from a genomic library. For plasmid isolation for highthroughput DNA sequencing using the R.E.A.L. Prep 96 Kit, cells are grown in 96-well plates (Qiagen, Valencia, CA, USA). After growth, the cells are concentrated by centrifugation and resuspended in buffer. We had difficulty resuspending the cells on the shaker of our robotic workstation (MultiPROBE $^{\circledR}$ IIEX; Packard Instrument, Meriden, CT, USA) but found that they could be resuspended easily by briefly vortex mixing the 96-well plates if a small glass bead was introduced into each well first. A simple device, called a Bead-Bop, was constructed to deliver the beads into the wells. Its construction is described below.

The Bead-Bop is constructed from materials that are readily available from a hobby shop and in a laboratory 